\title{
Mapping Vegetation and Forest Types using Landsat TM in the Western Ghat Region of Maharashtra, India
}

\author{
Sandipan Das \\ Symbiosis Institute of Geo-Informatics, \\ Symbiosis International University \\ Pune, India-411016.
}

\author{
T. P. Singh \\ Symbiosis Institute of Geo-Informatics, \\ Symbiosis International University \\ Pune, India-411016
}

\begin{abstract}
Vegetation plays a key role in reducing ambient temperature, moisture and pollutant capture, energy use and subsequent ground level ozone reduction. In recent years vegetation mapping has become increasingly important, especially with advancements in environmental economic valuation. The spatial information from the remote sensing satellites enables researchers to quantify and qualify the amount and health of vegetation. The present study highlights significance of remote sensing in the vegetation mapping of western ghat region of Maharashtra using satellite imageries from Landsat TM. A supervised (full Gaussian) maximum likelihood classification was implemented in our approach. The final classification product provided identification and mapping of dominant land cover types, including forest types and nonforest vegetation. Remote sensing data sets were calibrated using a variety of field verification measurements. Field methods included the identification of dominant forest species, forest type and relative state-of-health of selected tree species. Ground truth information was used to assess the accuracy of the classification. The vegetation type map was prepared from the classified satellite image. The moist deciduous forests constitute major portion of the total forest area. The application of remote sensing and satellites imageries with spatial analysis of land use land cover provides policy and decision makers with current and improved data for the purposes of effective management of natural resources.
\end{abstract}

\section{KEYWORDS}

Vegetation mapping, Remote sensing, Image classification, Western Ghat

\section{INTRODUCTION}

The accurate representation of terrestrial vegetation is a key requirement for global change research (Jung et al. 2006; Lambin et al. 2001). The vegetation map is an essential base map for managing natural resources as vegetation provides a base for all living beings and plays an essential role in affecting global climate change, such as influencing terrestrial $\mathrm{CO}_{2}$ (Xiao et al. 2004). In order to initiate vegetation protection and restoration programs, it is necessary to obtain current states of vegetation cover (Egbert et al. 2002; He et al. 2005). The traditional methods such as field surveys, literature reviews, map interpretation and collateral and ancillary data analysis), are not effective to acquire vegetation covers because they are time consuming, date lagged and often too expensive. In recent years remote sensing (RS) techniques are being widely used for vegetation mapping and monitoring (Boyd et al., 2003; Ingram, 2005; Lu et al., 2004;
Maynard et al., 2007; Dadhwal et al., 2009) which measures the spectral reflectance of the vegetation (Zianis et al., 2005). The remotely sensed spectral signatures are used for understanding the nature of vegetation characteristics, however it is affected by various factors like vegetation composition, soil characteristics, atmospheric conditions, topography and moisture content (Chen and Wang, 2008). The strengths of the techniques are to monitor terrestrial ecosystems at various temporal and spatial scales. Remote sensing has been the only feasible way of acquiring vegetation information over vast areas at a reasonable cost and acceptable accuracy due to repetitive data collection at a feasible effort (Lu, 2006). The developments in sensor technology have allowed the acquisition of remotely sensed data at a various range of scales ranging from coarse spatial resolution of $500 \mathrm{~m}$ (e.g., NOAA AVHRR, MODIS) to medium spatial resolution of 20_30 m (e.g., Landsat TM, Landsat ETM+, SPOT HRVIR) as well as high spatial resolution of less than $5 \mathrm{~m}$ (e.g., Ikonos, QuickBird, LIDAR, and others). The coarse spatial resolution optical sensors such as NOAA AVHRR (Dong et al., 2003) and MODIS (Baccini et al., 2004) have been useful for mapping vegetation at the global, continental, national and regional scale, because of spatial resolution, image coverage and high frequency in data acquisition ( $\mathrm{Lu}, 2006)$. The medium resolution satellite imagery such as Landsat TM is used at regional and at local scale for vegetation mapping. The optical moderate resolution sensors like Landsat Thematic Mapper (TM) has been the most frequently used RS data for vegetation mapping (Hall et al., 2006; Heiskanen, 2006; Ingram, 2005; Lu, 2006; Lu et al. 2004). The thematic mapper (TM) is an advanced, multispectral scanning, earth resources sensor designed to achieve higher image resolution, sharper spectral interval, improved geometric fidelity, and greater radiometric accuracy and resolution than that of the MSS sensor. TM images consist of seven spectral bands with a spatial resolution of 30 meters for Bands 1 to 5 and 7. Spatial resolution for Band 6 (thermal infrared) is 120 meters, but is resampled to 30 -meter pixels. This sensor also images a swath $185 \mathrm{~km}$ (115 miles) wide but each pixel in a TM scene represents a $30 \mathrm{~m}$ x $30 \mathrm{~m}$ ground area (except in the case of the far-infrared band 6 which uses a larger $120 \mathrm{~m}$ x $120 \mathrm{~m}$ pixel). The TM sensor has 7 bands that simultaneously record reflected or emitted radiation from the earth's surface in the blue-green (band 1), green (band 2), red (band 3), near-infrared (band 4), midinfrared (bands 5 and 7), and the far-infrared (band 6) portions of the electromagnetic spectrum. TM band 2 can observe green reflectance from healthy vegetation, and band 3 is designed for detecting chlorophyll absorption in vegetation. TM band 4 is ideal for near-infrared reflectance peaks in 
healthy green vegetation and for detecting water-land interfaces.

\section{STUDY AREA}

The Western Ghats is mega-biodiversity regions of the world. Twelve districts are covered in the Western Ghats region in Maharashtra. These districts are: Dhule, Nashik, Thane, Mumbai city, Mumbai sub urban, Pune, Raigarh, Ratnagiri, Sindhudurg, Satara, Sangli and Kolhapur. The present study has been conducted in Pune, Raigarh, Sindhudurg and Ratnagiri shown in Figure 1. It covers a geographical area of 36046 sq. $\mathrm{km}$ and located between north latitude $15^{\circ} 60^{\prime}$ and $19^{\circ} 39^{\prime}$ and east longitude $72^{\circ} 81^{\prime}$ and $75^{\circ} 16^{\prime}$. It is surrounded by Arabian Sea in the west, Kolhapur and Ahmadnagar districts in the east and Goa and Karnataka state in the south and Thane district in the north. It has semitropical climate and remains humid throughout the year. Its average annual precipitation varies from $2300 \mathrm{~mm}$ to about $4000 \mathrm{~mm}$ while annual mean temperature varies from $20^{\circ} \mathrm{C}$ to $24{ }^{\circ} \mathrm{C}$. The relief of the district is highly uneven, has a very narrow riverine plains that fringe the coastline and about 40 to $50 \%$ of the area is hilly. The altitude of the study area varies from 0 to $1480 \mathrm{~m}$. The elevation increases from western region $0 \mathrm{~m}$ along the coast rising up to an average elevation of 900$1400 \mathrm{~m}$ above mean sea level in eastern region.

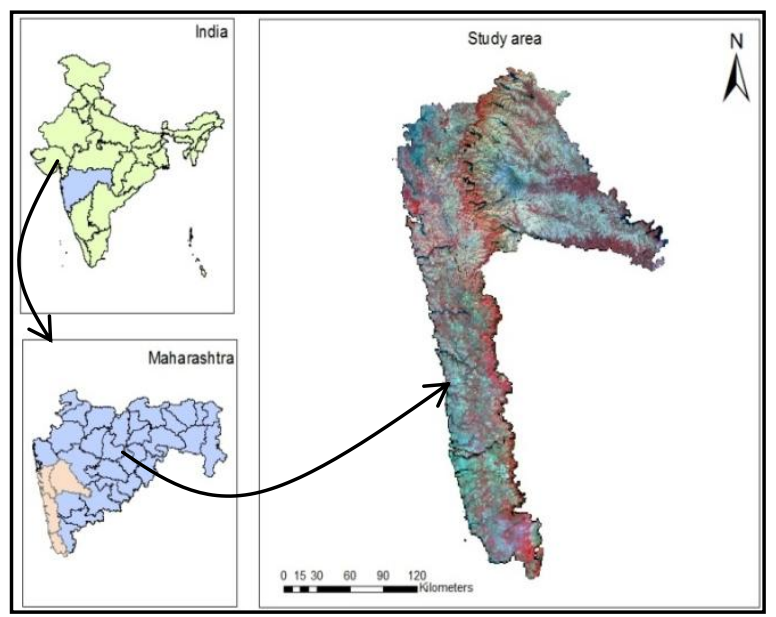

Figure 1:Location map of Study area

\section{MATERIALS AND METHODS}

Landsat TM FCC (bands 4, 3 and 2, scale 1: 50,000, October, 2009) were used for this study. The Landsat TM image was obtained in four separate images hence it was first mosaiced in Erdas Imagine software 10 before projecting it to UTM WGS 84 coordinate system. The study area was extracted by subsetting from the whole image. The flowchart of the research methodology can be divided into five stages: (i) preparation of reference maps for gathering the existing and relevant information in the spatial form, (ii) pre-field classification of the satellite data, (iii) ground truthing, (iv) post-field correction and (v) field verification of the final map. The spectral variation of each vegetation type were extracted from digital data by interpreting satellite images based on the interpretation elements such as the image color, texture, tone, pattern and association information etc. The standard "false color" composite. Vegetation looks in shades of red. Coniferous trees will seem darker red than hardwoods. This is a very popular band combination and is useful for vegetation studies. Usually, deep red hues indicate broad leaf and/or healthier vegetation while lighter reds signify grasslands or sparsely vegetated areas. Diverse methods have been developed to do this. Those methods can be broadly grouped into unsupervised classification or supervised classification depending on whether or not true ground data are inputted as references. The general steps involved in vegetation mapping include image preprocessing and image classification. The image preprocessing comprises certain preparatory steps necessary such as radiometric correction, geometric correction and image enhancement in order to improve the quality of original images, which then results in the assignment of each pixel of the scene to one of the vegetation groups defined in a vegetation classification system. Supervised classification was done with maximum likehood algorithm in Erdas Imagine software 10. Supervised classification techniques are based on external knowledge of the area displayed in the image. Supervised classification can be specified generally as the method of samples of known identity to classify pixels of unknown identity. Samples of known identity are those pixels placed within training areas. Pixels located within these areas term the training samples used to guide the classification algorithm to assigning particular spectral values to suitable informational class. The basic steps involved in a typical supervised classification procedure are 1) The training stage. 2) Feature selection. 3) Selection of appropriate classification algorithm 4) Post classification smoothening. 5) Accuracy assessment. Supervised classification techniques require prior knowledge of the number and, in the case of statistical classifiers, certain aspects of the statistical nature of the information classes with which the pixels establishing up an image are to be discovered. Training sites are areas representing each known land cover category that appear fairly homogeneous on the image (as determined by similarity in tone or color within shapes delineating the category). Specialists locate and circumscribe them with polygonal boundaries drawn on the image display. For each class thus outlined, mean values and variances of the DNs for each band used to classify them are measured from all the pixels enclosed in the site. More than one polygon can be established for any class. When DNs are plotted as a function of the band sequence (increasing with wavelength), the result is a spectral signature or spectral response curve for that class. In reality the spectral signature is for all of the materials within the site that interact with the incoming radiation. Classification now proceeds by statistical processing in which every pixel is compared with the various signatures and assigned to the class whose signature comes closest. A few pixels in a scene do not match and remain unclassified, because these may belong to a class not recognized or defined.

The maximum likelihood classifier calculates the probability that a pixel belongs to a class. Data from the training sets are assumed to be usually distributed, which allows the mean vector and the covariance matrix of the spectral cluster of each category of brightness values to be calculated (Lillesand and Kiefer, 2000). Supported on these results, the statistical probability of a pixel's brightness value consisting to each category of land use/cover can be calculated. The pixel is allotted to the category with the highest probability value. This classifier generally assumes equal probability of happening of each category of land use/cover. If experienced, one can define the probability of occurrence of each land-use/cover category before executing the image classification (known as a priori maximum likelihood classification).The necessary field corrections of the classified map were made and final vegetation map was prepared. The flow chart of the research methodology is shown in Figure 2. 


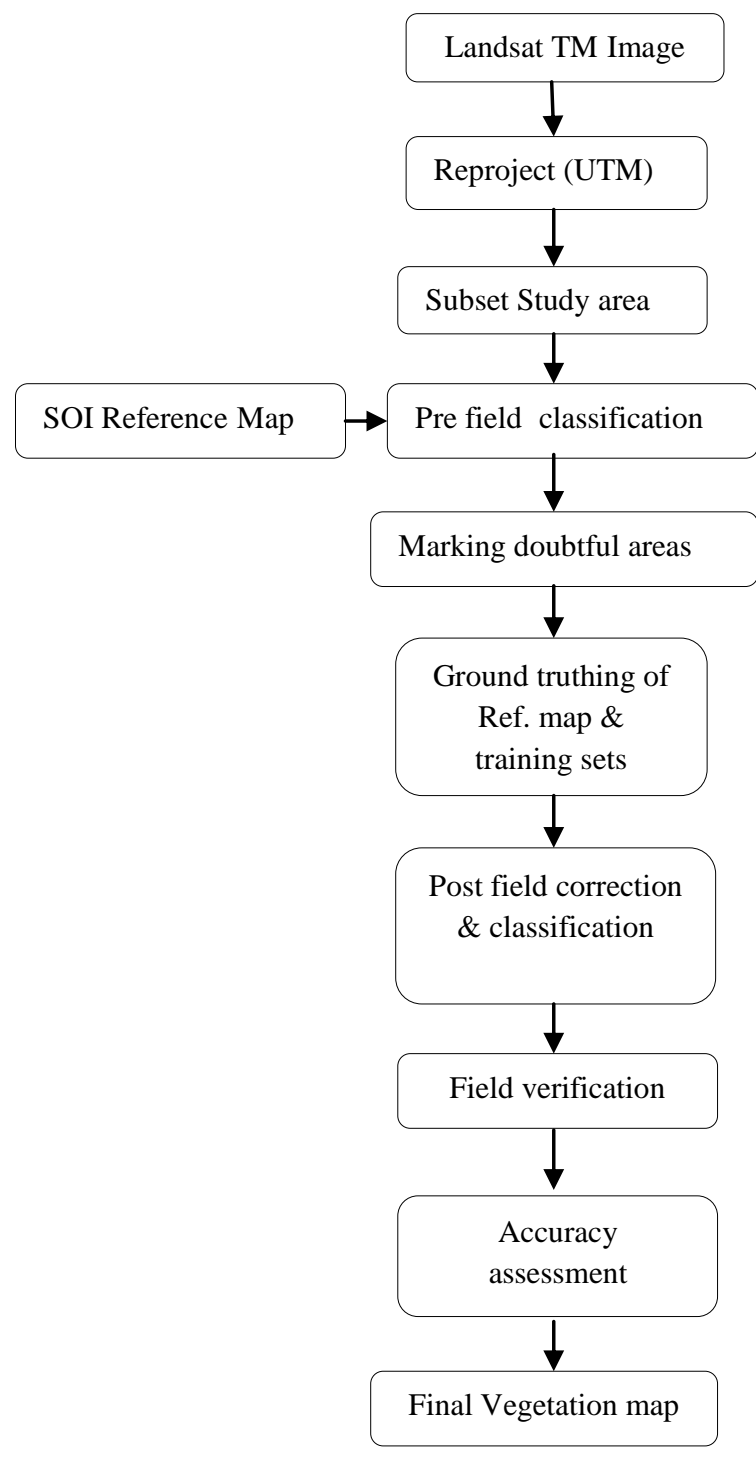

Figure 2: Flow Chart of Research Methodology

\section{RESULT AND DISCUSSION}

The vegetation map inferred from image classification is considered accurate if it provides a true representation of the region it portrays (Foody 2002; Weber 2006). The rectified LANDSAT TM scenes covering districts were analyzed to generate the vegetation map. All the major forest classes (viz. moist deciduous, semi evergreen, evergreen, dry deciduous, scrub forest and mangroves) were classified. Along with forest, other land use/ cover classes (viz. agriculture, settlement, open land, fallow land and water bodies) found in the districts were also classified. The description of forest types in the districts given by Champion \& Seth (1968) was particularly helpful in matching the climate and physiographic factors with the observed vegetation in different locations. The main tree species of this forest are Ain (Terminalia tomentosa), Jambha (Xylia dolabriformis), Kinjal (Terminalia paniculata), Sagwan (Tectona grandis), Surangi (Mammea suriga), Kokam (Garcinia indica), Kumbha (Careya arbprea), Karmal (Dillenia pentagyna), Amba (Mangifera Indica), Bibba (Semecarpus anacardium), Asana (Bridelia retusa), Anjani (Memocylon umbellatum ), Shisham (Dalbergia latifolia), and Khair (Acacia catechu . At several locations, the forests were found in the varying stages of degradation. The output classified map is shown in Figure 3.

The table 1 gives the statistics of the study area generated from the classified output of the Landsat TM data. Table 1 shows the spatial extent of land cover in square kilometer and in percentages.

Table 1: Statistics of the Study area

\begin{tabular}{|c|c|c|}
\hline $\begin{array}{c}\text { Landuse/cover } \\
\text { classes }\end{array}$ & Area $\mathbf{( K m}^{\mathbf{2}} \mathbf{)}$ & $\begin{array}{c}\text { Per cent of total } \\
\text { area }\end{array}$ \\
\hline Evergreen forest & 757.6 & 2.10 \\
\hline $\begin{array}{c}\text { Semi evergreen } \\
\text { forest }\end{array}$ & 1769.34 & 4.91 \\
\hline $\begin{array}{c}\text { Moist deciduous } \\
\text { forest }\end{array}$ & 6729.115 & 18.67 \\
\hline $\begin{array}{c}\text { Dry deciduous } \\
\text { forest }\end{array}$ & 1645.794 & 4.57 \\
\hline Mangroves & 168.46 & 0.47 \\
\hline Agriculture & 9159.42 & 25.41 \\
\hline Agriculture & 3441.08 & 9.55 \\
\hline Fallow land & 4477.54 & 12.42 \\
\hline Open land & 6144.36 & 17.05 \\
\hline Scrub land & 949.53 & 2.63 \\
\hline Water bodies & 531.09 & 1.47 \\
\hline Settlement & 273.31 & 0.76 \\
\hline Other classes \\
(shadow)
\end{tabular}

The total forest area is $30.72\left(11070.31 \mathrm{~km}^{2}\right)$ per cent of the total geographical area of the district. The moist deciduous forests constitute the bulk of the total forest area and were found in all the districts of study area. Around 61 per cent of the forest area belongs to moist deciduous forests. Evergreen forest is covered by 2.10 per cent area while Semi evergreen

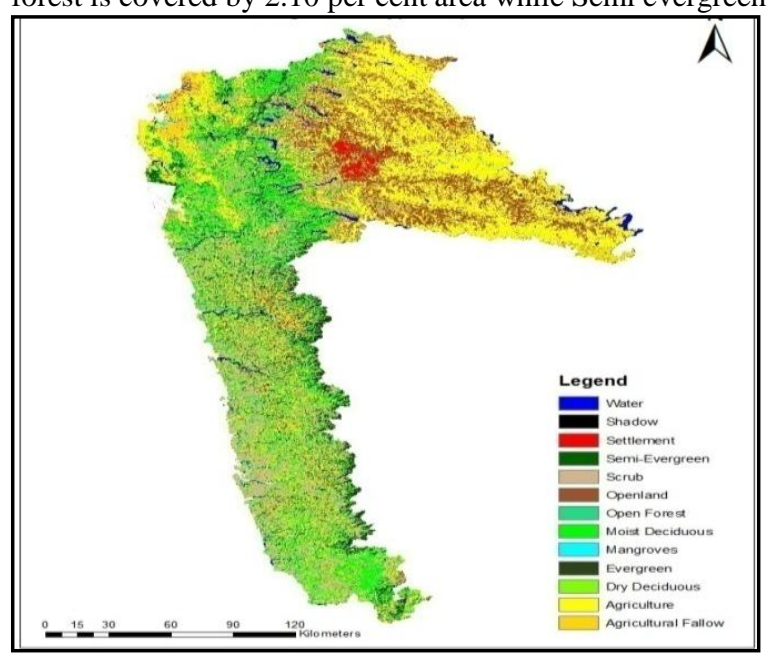

Figure 3: Vegetation Type map

and dry deciduous forest forms the remaining portion of the forest (Around 4.91 per cent under semi evergreen and 4.57 per cent under dry deciduous forest). Agriculture constitutes 34.96 per cent of total area. The water bodies cover 2.63 per cent $\left(949.53 \mathrm{~km}^{2}\right)$ area. Open land and scrub land covers an area of 29.47 per cent. The mangroves cover an area of 0.47 per cent and were found in the creeks of the districts of 
Raigad, Ratnagiri and Sindhudurg. The table 2, 3, 4 and 5 gives the forest type statistics of Pune, Sindudurg, Raigad, and Ratnagiri districts generated from the classified output of the Landsat TM data.

Table 2: Area under different forest type for Pune district

\begin{tabular}{|c|c|c|}
\hline Forest type & Area $\left(\mathbf{K m}^{\mathbf{2}}\right)$ & $\begin{array}{c}\text { Per cent of } \\
\text { total area }\end{array}$ \\
\hline $\begin{array}{c}\text { Semi evergreen } \\
\text { forest }\end{array}$ & 211.44 & 1.35 \\
\hline $\begin{array}{c}\text { Moist deciduous } \\
\text { forest }\end{array}$ & 1442.97 & 9.22 \\
\hline $\begin{array}{c}\text { Dry deciduous } \\
\text { forest }\end{array}$ & 173.51 & 1.10 \\
\hline
\end{tabular}

Table 3: Area under different forest type for Sindhudurg district

\begin{tabular}{|l|l|l|}
\hline Forest type & Area $\left(\mathbf{K m}^{\mathbf{2}}\right)$ & $\begin{array}{l}\text { Per cent of } \\
\text { total area }\end{array}$ \\
\hline Evergreen forest & 296.232 & 5.82 \\
\hline $\begin{array}{l}\text { Semi evergreen } \\
\text { forest }\end{array}$ & 385.230 & 7.57 \\
\hline $\begin{array}{l}\text { Moist deciduous } \\
\text { forest }\end{array}$ & 1382.060 & 27.17 \\
\hline
\end{tabular}

Table 4: Area under different forest type for Raigad district

\begin{tabular}{|l|l|l|}
\hline Forest type & Area $\left.\mathbf{( K m}^{\mathbf{2}}\right)$ & $\begin{array}{l}\text { Per cent of total } \\
\text { area }\end{array}$ \\
\hline Evergreen forest & 189.61 & 2.65 \\
\hline $\begin{array}{l}\text { Semi evergreen } \\
\text { forest }\end{array}$ & 560.67 & 7.83 \\
\hline $\begin{array}{l}\text { Moist deciduous } \\
\text { forest }\end{array}$ & 2155 & 30.13 \\
\hline Dry deciduous forest & 144.83 & 2.02 \\
\hline Mangroves & 35.88 & 0.50 \\
\hline
\end{tabular}

Table 5: Area under different forest type for Ratnagiri district

\begin{tabular}{|l|l|l|}
\hline Forest type & Area $\left(\mathbf{K m}^{\mathbf{2}}\right)$ & $\begin{array}{l}\text { Per cent of total } \\
\text { area }\end{array}$ \\
\hline Evergreen forest & 280.22 & 3.31 \\
\hline $\begin{array}{l}\text { Semi evergreen } \\
\text { forest }\end{array}$ & 1400.69 & 16.57 \\
\hline $\begin{array}{l}\text { Moist deciduous } \\
\text { forest }\end{array}$ & 1920.30 & 22.73 \\
\hline Mangroves & 25.37 & 0.30 \\
\hline
\end{tabular}

The accuracy assessment is often employed to determine the degree of 'correctness' of the classified vegetation groups compared to the actual ones. The accuracy assessment in the first stage is done by visual inspection of derived maps; however the method is highly subjective and often not accurate. The second stage is more objective methods in which comparisons of the area extents of the classes in the derived thematic maps (e.g. the percentage of a specific vegetation group in area) are made with the corresponding extents on ground or in other reference dataset. The accuracy assessment is important to qualify the result of image classification. In the present study vegetation classified map were compared with reference dataset of FSI report of year 2009 and was found in agreement with acceptable level of accuracy. This study area had 30.24 per cent forest cover. These figures are comparable with the figures given by FSI (2009) which found 31.39 per cent forest for the study area.
Accuracy assessment for the forest type mapping was done with randomly selected sample distribution points on the ground and tallied with represented data. The classification was validated with 90 randomly selected sample points. The total accuracy of the forest cover mapping therefore comes to be $85.10 \%$. The discrepancy in the forest area may be due to time on which the satellite data for the present study was acquired.

\section{CONCLUSION}

The present study demonstrated effective role of the spatial technologies in mapping vegetation types. The results of vegetation mapping from remote sensing imagery represents well with actual vegetation community composition. The optimal use of satellite imagery in vegetation mapping is effective when it is complemented with fieldwork. When selecting a right vegetation classification system for better classification accuracy, the following points should be taken into consideration (i) refining class definitions to decrease ambiguity, (ii) adding sufficient number of new classes to describe the complexity of local vegetation patterns and (iii) using a higher level of classification (Rapp et al. 2005). To map vegetation under such circumstances various difficulties are often encountered hence it is better to adopt more advanced image classification method such as sub-pixel analysis (Lee and Lathrop 2005). Another solution is to choose higher resolutions of imagery so as to increase the distinguishable possibility in image classification (Cingolani et al. 2004), however higher resolutions of imagery will most likely increase the cost. Though there are some standard methods for image preprocessing, however there are no super image classifiers that can be uniformly applicable to all applications, hence it is hot research topic, to apply effective classifiers or to develop new powerful classifiers suitable for specific applications. It is preferable for production of good quality vegetation maps to use data acquired from the same sources and at the same period and applying the same processing methods for the entire region. The present study can be used as baseline information for policy and decision makers to develop sound management strategies for effective natural resource management of the study area.

\section{REFERENCES:}

[1] Baccini, A., Friedl M. A., Woodcock, C E.,\& Warbington, R., (2004).Forest biomass estimation over regional scales using multisource data. Geophysical Research Letters, 31(10).

[2] Buddenbaum, H., Schlerf, M., Hill, J., (2005). Classification of coniferous tree species and age classes using hyperspectral data and geostatistical methods. International Journal of Remote Sensing, 26(24):54535456.

[3] Baret, F., \& Guyot, G., (1991). Potentials and limits of vegetation indices for LAI and APAR assessment. Remote Sensing of Environment, 35:161-173.

[4] Chen, G., and Wang, J.W., (2008). Spectral reflectance and aboveground biomass estimation of the grassland under protection condition. Journal of Yunnan Agricultural University, 23:462-467.

[5] Champion, H.G. \& S.K. Seth. 1968. A Revised Survey of the Forest Types of India. Govt. of India Publications, New Delhi. 
[6] Cingolani AM, Renison D, Zak MR, et al. (2004) Mapping vegetation in a heterogeneous mountain rangeland using landsat data: an alternative method to define and classify land-cover units. Remote Sens Environ 92:84-97.

[7] Dadhwal, V.K., Singh, S., Patil, P., (2009). Assessment of phytomass carbon pools in forest ecosystems in India. NNRMS Bulletin, 41-57.

[8] Dong, J., Kaufmann, R.K., Myneni, R.B., Tucker, C.J., Kauppi, P.E., Liski, J. Buermann, W., Alexeyev, V. and Hughes, M.K., (2003). Remote sensing estimation of boreal and temperate forest woody biomass: carbon pools, sources and sinks. Remote Sensing of Environment, 84: 393-410.

[9] Egbert SL, Park S, Price KP, et al. (2002) Using conservation reserve program maps derived from satellite imagery to characterize landscape structure. Comput Electron Agric 37:141-56.

[10] Foody, G.M., Boyd, D.S. and Cutler, M.E.J., (2003). Predictive relations of tropical forest biomass from Landsat TM data and their transferability between regions. Remote Sensing of Environment, 85(4):463-474.

[11] Foody GM (2002) Status of land cover classification accuracy assessment. Remote Sens Environ 80:185-201.

[12] He C, Zhang Q, Li Y, et al. (2005) Zoning grassland protection area using remote sensing and cellular automata modeling - a case study in Xilingol steppe grassland in northern China. J Arid Environ 63:814-26.

[13] Hall, R.J., Skakun, R.S., Arsenault, E.J. and Case, B.S., (2006). Modeling forest stand structure attributes using Landsat ETM+ data: Application to mapping of aboveground biomass and stand volume. Forest Ecology and Management, 225(1-3): 378-390.

[14] Heiskanen, J., (2006). Estimating aboveground tree biomass and leaf area index in a mountain birch forest using ASTER satellite data. International Journal of Remote Sensing, 27(6):1135-1158.

[15] Ingram, J.C., Dawson, T.P., and Whittaker, R.J., (2005). Mapping tropical forest structure in southern Madagascar using remote sensing and artificial neural networks. Remote Sensnig of Environment, 94:491-507.
[16] India State of Forest Report, (2009). Forest Survey of India, FSI (Ministry of Environment and Forest), Dehradun, India.

[17] Jung M, Churkina G, Henkel K, et al. (2006) Exploiting synergies of global land cover products for carbon cycle modeling. Remote Sens Environ 101:534-53.

[18] Lambin EF, Turner BL, Helmut J, et al. (2001) The causes of land-use and land-cover change: moving beyond the myths. Glob Environ Chang 11:261-9.

[19] Lu, D., Mausel, P., Brondizio, E. and Moran, E., (2004). Relationships between forest stand parameters and Landsat TM spectral responses in the Brazilian Amazon Basin. Forest Ecology and Management, 198:149-167.

[20] Lee S, Lathrop RG (2005) Sub-pixel estimation of urban land cover components with linear mixture model analysis and Landsat Thematic Mapper imagery. Int J Remote Sens 26:4885-905.

[21] Maynard, C.L., Lawrence, R.L., Nielsen, G.A. and Decker, G., (2007). Modeling vegetation amount using bandwise regression and ecological site descriptions as an alternative to vegetation indices. GIScience and Remote Sensing, 44(1):68-81.

[22] Rapp J, Lautzenheiser T, Wang D, et al. (2005) Evaluating error in using the national vegetation classification system for ecological community mapping in Northern New England, USA. Nat Areas J 25:46-54.

[23] Weber KT (2006) Challenges of integrating geospatial technologies into rangeland research and management. Rangeland Ecol Manage 59:38-43.

[24] Xiao XM, Zhang Q, Braswell B, et al. (2004) Modeling gross primary production of temperate deciduous broadleaf forest using satellite images and climate data. Remote Sens Environ 91:256-70.

[25] Zianis, D., Muukkonen, P., Mäkipää, R., \& Mencuccini, M. (2005). Biomass and stem volume equations for tree species in Europe. Silva Fennica Monographs, 4:1-63. 